\title{
Simultaneous Determination of Acetaminophen, Pamabrom and Pyrilamine Maleate in Pharmaceutical Formulations Using Stability Indicating HPLC Assay Method
}

\author{
${ }^{1,3}$ Atif Saleem, ${ }^{1}$ Shahid Anwar, ${ }^{1}$ Talib Hussain, ${ }^{2}$ Rehan Ahmad, ${ }^{3}$ Ghulam Mustafa and ${ }^{3}$ Muhammad Ashfaq ${ }^{*}$ \\ 1 Department of Chemistry, Minhaj University, Lahore-54000, Pakistan \\ 2 CCL Pharmaceuticals (Pvt.) Ltd, Lahore-54000, Pakistan \\ 3 Department of Chemistry, University of Gujrat, H.H. Campus, Gujrat-50700, Pakistan \\ * Author for Correspondence, e-mail: m.ashfaq@uog.edu.pk Ph\#+92333-4043110
}

Received May 15 ${ }^{\text {th }}, 2014$; Accepted February $17^{\text {th }}, 2015$

\begin{abstract}
A simple, specific and accurate stability indicating RPHPLC method was developed for the determination of acetaminophen, pamabrom and pyrilamine maleate simultaneously in pharmaceutical dosage forms. Successful separation of all the components was enacted within 10 min using C18 column with mobile phase of methanol and acidified water $(\mathrm{pH} 1.8)$ in the ratio of $(27: 73$ $\mathrm{v} / \mathrm{v}$ respectively). Flow rate of the mobile phase was $1.5 \mathrm{~mL} / \mathrm{min}$ with detection at $300 \mathrm{~nm}$. The method was validated in accordance with ICH guidelines. Response was a linear function of concentration over the range of $50-150 \mu \mathrm{g} / \mathrm{mL}$ for acetaminophen, $2.5-7.5 \mu \mathrm{g} /$ $\mathrm{mL}$ for pamabrom and $1.5-4.5 \mu \mathrm{g} / \mathrm{mL}$ for pyrilamine maleate. The method resulted in excellent separation of all the analytes along with their stress induced degradation products with acceptable peak tailing and good resolution. It is therefore can be applied successfully for simultaneous determination of acetaminophen, pamabrom and pyrilamine maleate in pharmaceutical formulations and their stability studies.
\end{abstract}

Key words: RP-HPLC, Acetaminophen, Pamabrom, Pyrilamine, ICH guidelines.

\section{Introduction}

Acetaminophen commonly called Paracetamol is chemically designated as 4-hydroxyacetanalide (Fig. 1). It shows both analgesic and antipyretic properties and is available from the open market without prescription as well as through prescription. Different dosage forms of paracetamol such as tablet, capsules, drops etc. are available in the open market and its different combinations with other drugs have been enlisted in pharmacopeias. [1-2] Pamabrom (Fig. 2) is a common diuretic existed as 1:1 mixture of 8-Bromo-3,7-dihydro-1,3-dimethyl-1$H$-purine-2,6-dione and 2-amino-2-methyl-1-propanol, where 8-Bromo-3,7-dihydro-1,3-dimethyl-1- $H$-purine-2,6-dione is the active diuretic agent. [3] Pyrilamine maleate (Fig. 3) having the chemical name 1,2-Ethanediamine, N-[(4-methoxyphenyl) methyl]-N', N'-dimethyl-N-2-pyridinyl-,(Z)-2-butenedioate (1:1)
Resumen. Se ha desarrollado un procedimiento simple y específico procedimiento para la determinación de acetaminofeno, pamabrom y maleato de pirilamina en formulaciones farmacéuticas por HPLC en fase inversa. La separación de todos los componentes se obtuvo en 10 min utilizando una columna C18 y la fase móvil compuesta por metanol y solución acuosa a pH 1.8 (con ácido sulfúrico) en relación 27: $73 \mathrm{v} / \mathrm{v}$. La velocidad del flujo en la columna fue de $1.5 \mathrm{~mL} / \mathrm{min}$ y la detección espectrofotométrica en $300 \mathrm{~nm}$. El método fue validado siguiendo los criterios ICH. La respuesta fue lineal en el intervalo de concentraciones 50- $150 \mu \mathrm{g} / \mathrm{mL}$ para acetaminofeno, $2.5-7.5 \mu \mathrm{g} / \mathrm{mL}$ para pamabrom y $1.5-4.5 \mu \mathrm{g} / \mathrm{mL}$ para maleato de pirilamina. El procedimiento permitió la separación de los tres analitos y de sus productos de degradación inducidos en condiciones de estrés con aceptable simetría de picos y resolución cromatográfica. Es por ello que este procedimiento puede ser empleado para la determinación de acetaminofeno, pamabrom y maleato de pirilamina en formulaciones farmacéuticas y en estudios de su estabilidad.

Palabras clave: Cromatografía de líquidos de alta resolución en fase inversa (RP-HPLC), Acetaminofoeno, Pamabrom, Pirilamina, criterios ICH (Conferencia Internacional sobre Armonización de los Requisitos Técnicos para el Registro de Productos Farmacéuticos para Uso Humano).

is an antihistamine used to reduce the allergic conditions and reduce symptoms of cold. [4]

The combination of three active ingredients acetaminophen, pamabrom and pyrilamine is used for the treatment of symptoms of mild to moderate premenstrual syndrome in addition to additive effects as analgesic as wells as antihistamine and mild diuretic effects.[5] This combination is available in different strengths in different dosage form with various brand names. Most common are the tablet dosage form having strength of $500 \mathrm{mg}, 25 \mathrm{mg}$ and $15 \mathrm{mg}$ respectively of Acetaminophen, Pamabrom and Pyrilamine.

Literature review did not provide any analytical method for the simultaneous determination of above three components. Individual search of the three components regarding their analytical methods revealed a flood of HPLC methods for acetaminophen either individually or in combination with other 
active ingredients. [6-17] The search of the other two components viz. pamabrom and pyrilamine resulted in only few analytical methods. [18-21]

The fixed dose combination containing acetaminophen, pamabrom and pyrilamine maleate is available in the market in many countries yet no official pharmacopoeia has adopted that combination. Literature review also resulted in failure of any reported HPLC method for the simultaneous determination of these three drugs in fixed dose combination. Therefore efforts were done to develop and validate RP-HPLC method for simultaneous determination of these drugs and their stress induced degradation products in pharmaceutical formulations. The described method is able to separate all three drugs from the stress induced degradation within $10 \mathrm{~min}$, so it can be used for stability studies also.

\section{Results and discussion}

\section{Method Development and Optimization}

The main objective of this research work was to achieve the best conditions for separation of acetaminophen, pamabrom and pyrilamine maleate simultaneously in their fixed dose combination.

Initially various mobile and stationary phases were tried to accomplish the best separation conditions and resolution be-

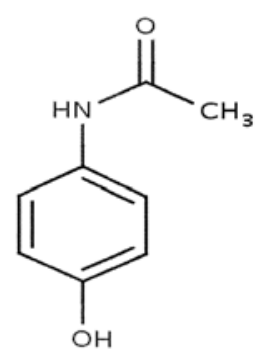

Fig. 1. Chemical Structure of Acetaminophen
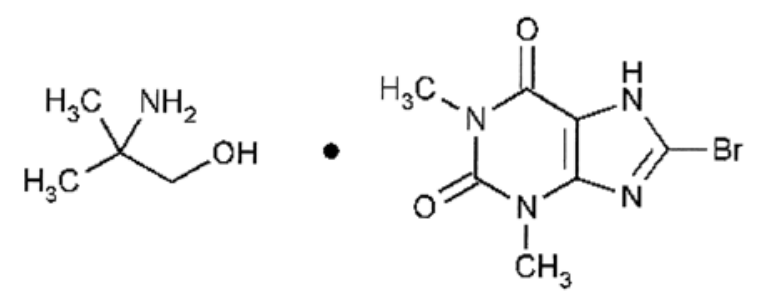

Fig. 2. Chemical Structure of Pamabrom

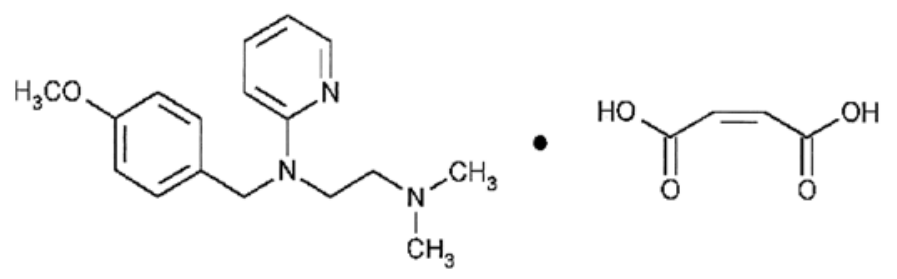

Fig. 3. Chemical Structure of Pyrilamine Maleate tween acetaminophen, pamabrom and pyrilamine maleate. For the initial trial, Hypersil BDS C8 column was chosen with mobile phase consisting of $1 \mathrm{M}$ Potassium dihydrogen phosphate and acetonitrile in different ratios $(50: 50,40: 60,30: 70,20$ $: 80$ ). Under all these condition elution of acetaminophen occurred only and there was no separation between pamabrom and pyrilamine maleate.

Then stationary phase was switched to Cyano column using same ratios of $1 \mathrm{M}$ Potassium dihydrogen phosphate and acetonitrile as they were used with Hypersil BDS C8 column. Here also the elution of acetaminophen occurred with good peak shape but remaining two peaks remain merged with each other. $\mathrm{pH}$ of $1 \mathrm{M}$ Potassium dihydrogen phosphate was varied from 2 - 7 in order to separate the merged components but all attempts remained fruitless.

Further trials were carried out using Promosil C18 column but result was the same as for other two columns. Then mobile phase was changed from buffer to acidified water and methanol was used instead of acetonitrile with different concentrations $(50: 50,40: 60,30: 70,20: 80)$ and with different $\mathrm{pH}$ values of acidified water $(1.5-4.5)$. The trick works here and all the three components were eluted. At last, mobile phase of acidified water $(\mathrm{pH} \mathrm{1.8)}$ and methanol in the ratio of 73: 27 was selected that provides best separation conditions for the mentioned three components along with $\mathrm{C} 18$ column. Under these conditions tailing of all the components was less than 1.5 with retention times of 2.0, 2.8 and 7.5 minutes for acetaminophen, pamabrom and pyrilamine maleate at a flow rate of $1.5 \mathrm{ml}$ per minute.

\section{Analytical method validation}

The developed analytical method was validated using $\mathrm{ICH}$ guidelines. [22] Linearity, accuracy, precision, robustness, specificity, stability of solutions and limit of detection and quantitation were performed.

Linear calibration plots of the proposed method were obtained over concentration ranges of $50-150 \mu \mathrm{g} / \mathrm{mL}(50,60,70$, $80,90,100,110,120,130,140$ and $150 \mu \mathrm{g} / \mathrm{mL})$ for acetaminophen, 2.5-7.5 $\mu \mathrm{g} / \mathrm{mL}$ for pamabrom $(2.5,3.0,3.5,4.0,4.5$, 5.0, 5.5, 6.0, 6.5, 7.0 and $7.5 \mu \mathrm{g} / \mathrm{mL})$ and $1.5-4.5 \mu \mathrm{g} / \mathrm{mL}$ for pyrilamine maleate $(1.5,1.8,2.1,2.4,2.7,3.0,3.3,3.6,3.9$, $4.2,4.5)$. The linear regression equation for acetaminophen was $\mathrm{Y}=12039 \mathrm{X}+401076$ with correlation coefficient of 0.9993 . For pamabrom, it was $\mathrm{Y}=1246.9 \mathrm{X}+30914$ with correlation coefficient of 0.9993 and for pyrilamine maleate it was $\mathrm{Y}=$ $1579.5 \mathrm{X}+38151$ with correlation coefficient of 0.9995 . The graphics of linearity are shown in Figs. 4-6.

The limit of detection (LOD) and quantitation (LOQ) were determined by making serials of dilutions. LOD was found to be $0.23 \mu \mathrm{g} / \mathrm{mL}$ for acetaminophen, $0.09 \mu \mathrm{g} / \mathrm{mL}$ for pamabrom and $0.26 \mu \mathrm{g} / \mathrm{mL}$ for pyrilamine maleate respectively (signal to noise ratio of 3: 1). LOQ was found to be $0.77 \mu \mathrm{g} / \mathrm{mL}$ for acetaminophen, $0.30 \mu \mathrm{g} / \mathrm{mL}$ for pamabrom and $0.87 \mu \mathrm{g} / \mathrm{mL}$ pyrilamine maleate respectively (signal to noise ratio of 10: 1).

Accuracy of the method was evaluated in triplicates using standard addition technique at three concentration levels i.e. 


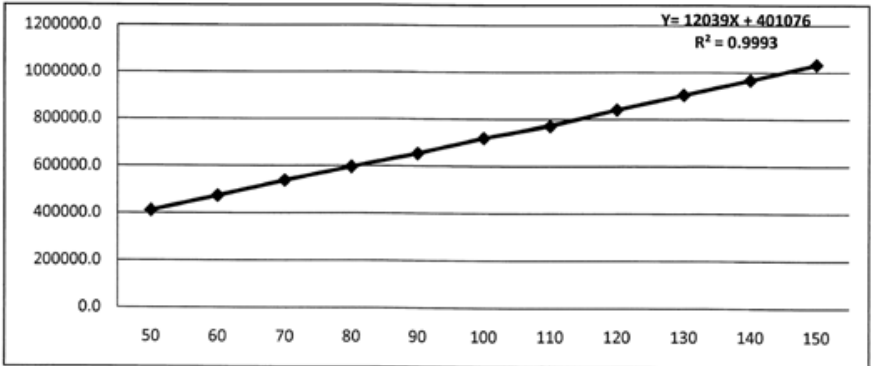

Fig. 4. Linearity graph for acetaminophen

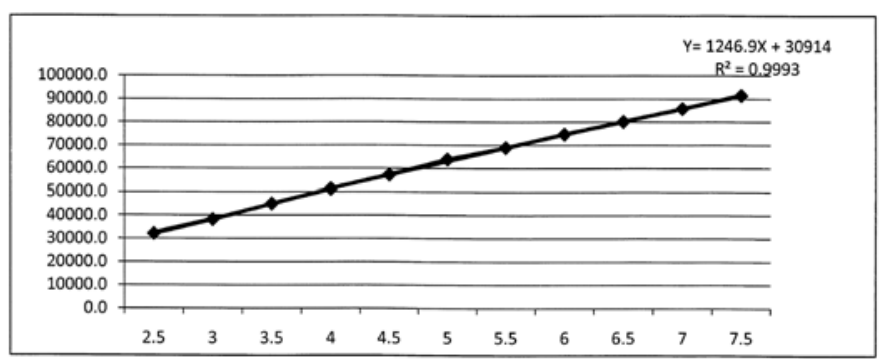

Fig. 5. Linearity graph for pamabrom

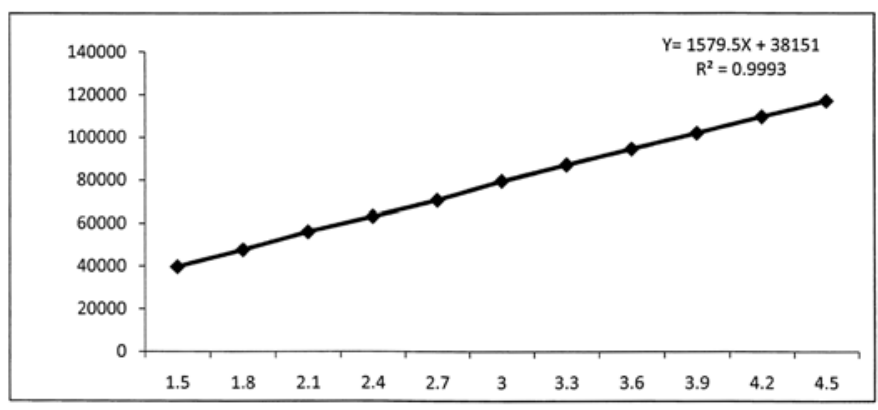

Fig. 6. Linearity graph for pyrilamine maleate
$80 \%, 100 \%$ and $120 \%$ of target test concentration $(100 \mu \mathrm{g} /$ $\mathrm{mL}$ of acetaminophen, $5 \mu \mathrm{g} / \mathrm{mL}$ of pamabrom \& $3 \mu \mathrm{g} / \mathrm{mL}$ of pyrilamine maleate). Percentage recoveries along with standard deviation and relative standard deviations for each analyte are given in Table 1. Recovery studies showed the method to be highly accurate and suitable for intended use.

For intra-day precision, three set of concentrations of acetaminophen, pamabrom and pyrilamine maleate were tested six times within the same day. For intermediate precision, two different analysts from the same Laboratory tested the same three concentrations six times. Relative standard deviation (RSD \%) of the peak area was then calculated. The results of intra-day and inter-day precision are presented in Table 2.

For carrying out the robustness, very small changes were carried out in mobile phase composition, flow rate and $\mathrm{pH}$ of acidified water. The results (Assay, tailing factor, theoretical plates and resolution) showed that slight variations in chromatographic conditions had negligible effect on the chromatographic parameters. All the chromatographic parameters remained within the acceptable criteria as described earlier. It was thus concluded that the method is robust for the intended use.

Specificity of the developed method was evaluated by applying different stress conditions (acid, base, oxidation, thermal, humidity and photolytic) to acetaminophen, pamabrom and pyrilamine maleate in combination form. From the result of forced degradation studies, it is clear that all the three components remain intact under heat stress and humid conditions. In acidic conditions, acetaminophen and pyrilamine maleate were degraded up to $4 \%$ whereas no degradation was observed for pamabrom. Basic stress caused the degradation of acetaminophen and pyrilamine up to 12.5 and $13.8 \%$ respectively. Remarkable degradation was observed in case of pamabrom and pyrilamine maleate in oxidative conditions, where pamabrom and pyrilamine maleate were degraded up to $10.6 \%$ and

Table 1. Accuracy of the Proposed HPLC Method

\begin{tabular}{|c|c|c|c|c|}
\hline Drugs & Spiked Concentration $\left(\mu \mathrm{g} \mathrm{mL}^{-1}\right)$ & Recovery (\%) & $\mathrm{SD}$ & $\mathrm{RSD}(\%)$ \\
\hline \multirow[t]{2}{*}{ Acetaminophen } & 80.0 & 102.7 & 0.28 & 0.27 \\
\hline & 100.0 & 100.8 & 0.09 & 0.09 \\
\hline \multirow[t]{2}{*}{ Pamabrom } & 4.0 & 99.3 & 0.39 & 0.39 \\
\hline & 5.0 & 101.7 & 0.37 & 0.36 \\
\hline \multirow{2}{*}{ Pyrilamine } & 3.0 & 100.1 & 0.41 & 0.41 \\
\hline & 3.6 & 103.1 & 0.18 & 0.17 \\
\hline
\end{tabular}

Table 2. Intra-Day and Intermediate Precision of the Proposed HPLC Method

\begin{tabular}{cccc}
\hline Ingredient & $\mathrm{n}$ & $\begin{array}{c}\text { Repeatability } \\
\pm \mathrm{RSD}(\%)\end{array}$ & $\begin{array}{c}\text { Intermediate Precision } \\
\pm \mathrm{RSD}(\%)\end{array}$ \\
\hline Acetaminophen & 18 & 0.06 & 0.13 \\
Pamabrom & 18 & 0.56 & 0.71 \\
Pyrilamine & 18 & 0.88 & 1.13 \\
\hline
\end{tabular}




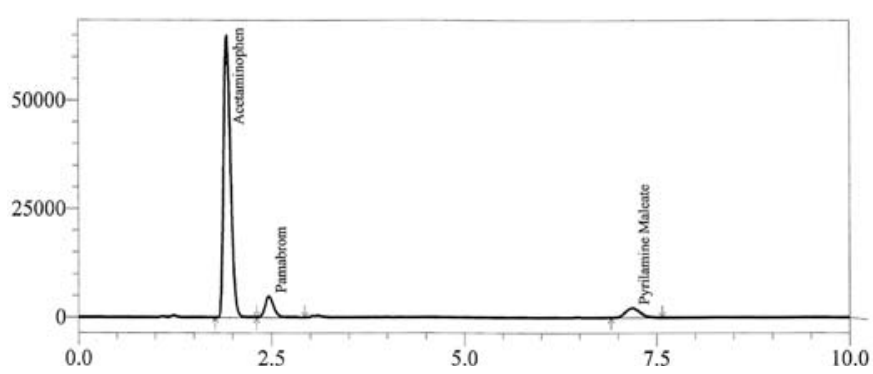

Fig. 7. Chromatogram of acetaminophen, pamabrom and pyrilamine maleate standard

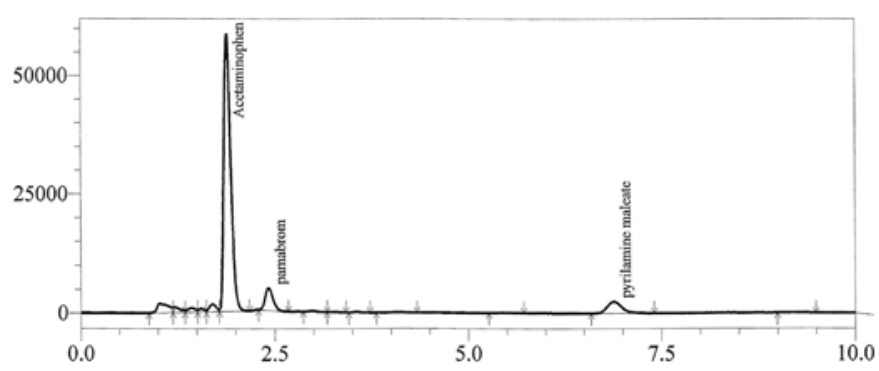

Fig. 8. Chromatogram of acetaminophen, pamabrom and pyrilamine maleate under basic stress

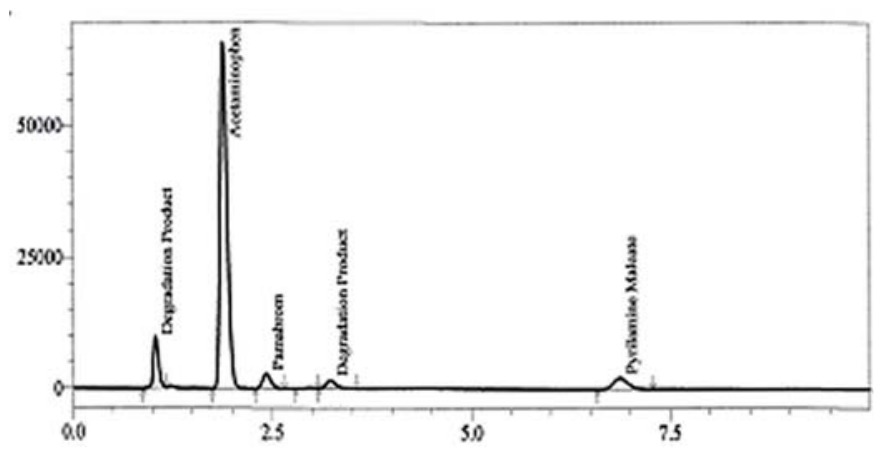

Fig. 9. Chromatogram of acetaminophen, pamabrom and pyrilamine maleate under oxidative stress

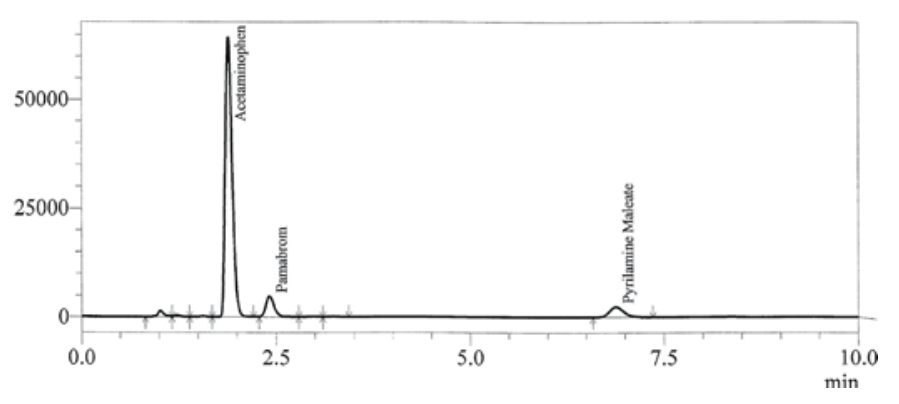

Fig. 10. Chromatogram of acetaminophen, pamabrom and pyrilamine maleate under acidic stress

$44 \%$ respectively. The amount degraded was calculated by subtracting the recovered amount in each stress condition from the recovered amount of un-stressed samples. The representative chromatograms under all the stress conditions are shown in Figs. s (7-10).
In addition to the percentage degradation of each drug, a number of degradation products (impurities) were produced under acidic, oxidative and photolytic stress conditions. The stress induced degradation products (impurities) were unique to acidic $(7.93,9.47 \mathrm{~min})$, oxidative $(3.82,6.16$, and 10.82 $\min )$ and photolytic $(5.10,6.09,7.17$, and 8.45$)$ stress conditions. The data is shown in Table 3.

\section{Application of the Method}

Application of the method was checked by analyzing the acetaminophen, pamabrom and pyrilamine maleate in commercially available pharmaceutical products. The results are provided in Table 4 which showed high percentage recoveries and low RSD (\%) values for both analytes.

\section{Experimental}

\section{Chemicals and Reagents}

Reference standards of acetaminophen, pamabrom and pyrilamine maleate with stated purity of $98.81,99.12$ and $99.20 \%$ respectively were obtained from CCL Pharmaceuticals (Lahore, Pakistan). Femistar tablet claimed to contain $500 \mathrm{mg}$ per tablets of acetaminophen, $25 \mathrm{mg}$ per tablets of pamabrom and $15 \mathrm{mg}$ per tablet of pyrilamine maleate were used in this study. Methanol (HPLC grade), sulphuric Acid, hydrochloric acid, sodium hydroxide and hydrogen peroxide (analytical reagent grade) were of Fluka and were purchased from their local agent in Lahore, Pakistan. Mobile phase was filtered using $0.45 \mu \mathrm{m}$ nylon filters by Millipore (USA).

\section{Equipment and Chromatographic Conditions}

HPLC apparatus consisted of Shimadzu LC-20A system (Kyoto, Japan) with auto sampler and UV detector set at $300 \mathrm{~nm}$. BDS Promosil C18 column $(250 \times 4.6 \mathrm{~mm}, 5 \mu \mathrm{m}$ particle size $)$ was used for carrying out all the experimental work. Acidified water $(\mathrm{pH} 1.8)$ and methanol in the ratio of $(73: 27 \mathrm{v} / \mathrm{v}$ respectively) were used as mobile phase at a flow rate of $1.5 \mathrm{~mL} / \mathrm{min}$. All chromatographic experiments were performed at room temperature $\left(25^{0} \mathrm{C} \pm 2^{0} \mathrm{C}\right)$.

\section{Preparation of Mobile Phase}

Mobile phase was prepared by mixing acidified water ( $\mathrm{pH} 1.8)$ and methanol in the ratio of $(73: 27 \mathrm{v} / \mathrm{v}$ respectively). Acidified water was prepared using sulphuric acid and then dilution to set $\mathrm{pH} 1.8$ with water.

\section{Preparation of Standard Solution}

$500 \mathrm{mg}$ acetaminophen, $25 \mathrm{mg}$ of pamabrom and $15 \mathrm{mg}$ of pyrilamine maleate were accurately weighed in $100 \mathrm{ml}$ flask, dissolved and then diluted with mobile phase. This solution was then further diluted to get the desired concentrations. 
Table 3. Stress Testing Results of Acetaminophen, Pamabrom, Pyrilamine Maleate

\begin{tabular}{lccc}
\hline \multicolumn{1}{c}{ Nature of stress } & $\begin{array}{c}\text { Recovery of Acetaminophen } \pm \text { RSD } \\
(\%)\end{array}$ & $\begin{array}{c}\text { Recovery of Pamabrom } \pm \text { RSD } \\
(\%)\end{array}$ & $\begin{array}{c}\text { Recovery of Pyrilamine } \pm \text { RSD } \\
(\%)\end{array}$ \\
\hline Heat stress & $100.60 \pm 0.22$ & $98.59 \pm 0.22$ & $97.41 \pm 2.14$ \\
$1 \mathrm{~N} \mathrm{HCl}$ & $95.97 \pm 0.08$ & $99.62 \pm 0.84$ & $95.47 \pm 1.31$ \\
$1 \mathrm{~N} \mathrm{NaOH}$ & $87.41 \pm 0.15$ & $100.42 \pm 0.29$ & $86.22 \pm 0.69$ \\
$10 \% \mathrm{H} 2 \mathrm{O} 2$ & $97.99 \pm 0.03$ & $89.40 \pm 0.44$ & $56.04 \pm 2.22$ \\
Humidity \& Light & $100.49 \pm 0.06$ & $98.94 \pm 0.77$ & $99.66 \pm 1.08$ \\
\hline
\end{tabular}

Table 4. Assay results of acetaminophen, pamabrom and pyrilamine maleate in commercial tablets

\begin{tabular}{clccc}
\hline Product & \multicolumn{1}{c}{ Ingredient } & $\begin{array}{c}\text { Label Value } \\
(\mathrm{mg} \text { per Tablet })\end{array}$ & $\begin{array}{c}\text { Found } \\
(\mathrm{mg})\end{array}$ & $\begin{array}{c}\text { Recovery } \pm \text { RSD } \\
(\%)\end{array}$ \\
\hline Femistar & Acetaminophen & 500 & 502.0 & $100.4 \pm 0.21$ \\
& Pamabrom & 25 & 24.96 & $99.84 \pm 0.75$ \\
& Pyrilamine & 15 & 15.04 & $101.33 \pm 0.88$ \\
\hline
\end{tabular}

$* \mathrm{n}=$ Average of 10 determinations

\section{Linearity}

Linear calibration plots of the proposed method were obtained by analyzing eleven solutions over concentration ranges of 50$150 \mu \mathrm{g} / \mathrm{mL}(50,60,70,80,90,100,110,120,130,140$ and 150 $\mu \mathrm{g} / \mathrm{mL})$ for acetaminophen, $2.5-7.5 \mu \mathrm{g} / \mathrm{mL}$ for pamabrom $(2.5$, $3.0,3.5,4.0,4.5,5.0,5.5,6.0,6.5,7.0$ and $7.5 \mu \mathrm{g} / \mathrm{mL})$ and 1.5$4.5 \mu \mathrm{g} / \mathrm{mL}$ for pyrilamine maleate $(1.5,1.8,2.1,2.4,2.7,3.0$, $3.3,3.6,3.9,4.2$ and $4.5 \mu \mathrm{g} / \mathrm{mL})$. Each solution was prepared in triplicate. The acceptance criterion was the value of correlation coefficient which should be close to 1 .

\section{Accuracy}

Accuracy of the method was evaluated in triplicates using standard addition technique at three concentration levels i.e. $80 \%$, $100 \%$ and $120 \%$ of target test concentration $(100 \mu \mathrm{g} / \mathrm{mL}$ of acetaminophen, $5 \mu \mathrm{g} / \mathrm{mL}$ of pamabrom \& $3 \mu \mathrm{g} / \mathrm{mL}$ of pyrilamine maleate). The recoveries of analytes were then calculated. Generally acceptable values for accuracy ranges from 95-105\%.

\section{Precision}

For intra-day precision, three set of concentrations of acetaminophen, pamabrom and pyrilamine maleate were tested six times within the same day. From these replicates, percentage RSD was calculated. For intermediate precision, two different analysts from the same Laboratory tested the same three concentrations six times. RSD was then calculated from those. RSD less than $2 \%$ is generally accepted for precision so this criterion was set as acceptable for this study.

\section{Specificity}

To demonstrate the stability indicating properties of the proposed method, accelerated degradation studies were performed on acetaminophen, pamabrom and pyrilamine in tablet dosage form by applying different stress conditions. The stress conditions employed include light \& humidity exposure, heat $\left(60{ }^{\circ} \mathrm{C}\right)$, acid $(1 \mathrm{~N} \mathrm{HCl})$, base $(1 \mathrm{~N} \mathrm{NaOH})$, and Oxidative $\left(10 \% \mathrm{H}_{2} \mathrm{O}_{2}\right)$ stress. The monitoring time was 24 hours for acid $(1 \mathrm{~N} \mathrm{HCl})$, base $(1 \mathrm{~N} \mathrm{NaOH})$, oxidative $(10 \%$ $\left.\mathrm{H}_{2} \mathrm{O}_{2}\right)$, light exposure and humidity stress and 60 minutes of heat stress $\left(60^{\circ} \mathrm{C}\right)$.

\section{Robustness}

For carrying out the robustness, very small changes were carried out in mobile phase composition, flow rate and $\mathrm{pH}$ of acidified water. The effect of these small changes on retention time, tailing factor, resolution and number of theoretical plates of each analyte was then assessed. Tailing factors less than 1.5, theoretical plates greater than 2000 and resolution greater than 1.5 was acceptable criteria for the proposed method.

\section{Solution stability and Mobile Phase stability}

To check the stability of all the three active components of this ternary combination in solution form, the solution of these components was placed in tight containers at room temperature for 48 hours and their stability was checked after each 12 hours period. Mobile phase stability was also checked by using 12-48 hour old mobile phase for the preparation of analyte solution and then calculating the recovery of the active components in that mobile phase solution.

\section{Application of the method in tablets}

20 tablets were weighed and the average weight was calculated. These tablets were then ground to fine powder. Weight of the powder equivalent to mean weight of one tablet of Femistar (composition $500 \mathrm{mg}$ acetaminophen, $25 \mathrm{mg}$ of pamabrom and $15 \mathrm{mg}$ of pyrilamine maleate per tablet) was diluted to $100 \mathrm{~mL}$ 
with mobile phase. $2 \mathrm{ml}$ of this solution was then diluted to 100 $\mathrm{mL}$ with mobile phase to obtain concentration equal to $100 \mu \mathrm{g} /$ $\mathrm{mL}$ of acetaminophen, $5 \mu \mathrm{g} / \mathrm{mL}$ of pamabrom and $3 \mu \mathrm{g} / \mathrm{mL}$ of pyrilamine maleate. Percentage recovery of each analyte was then calculated using the developed method. Percentage recovery from $95-105 \%$ was considered as acceptable for this study.

\section{Conclusions}

A simple, sensitive, isocratic and accurate reverse phase HPLC method has been described for simultaneous determination of acetaminophen, pyrilamine maleate and pamabrom in pharmaceutical formulations. The proposed method was validated by testing its linearity, accuracy, and precision, limits of detection and quantitation and specificity. The method was good enough to separate the peaks of active pharmaceutical ingredients (APIs) from the degradation products (produced during forced degradation studies). It is also clear from the chromatograms that both the active ingredient peaks in all the stress conditions were free from any sort of degradation impurities. All these convince us to conclude that the method can be successfully used for any sort of stability and validation studies.

\section{References}

1. Reynolds, J .E. F.; Martindale, The Extra Pharmacopoeia, 34th ed.; Pharmaceutical Press: London, 2005, p. 50-53.

2. The United States Pharmacopeia, 24th ed.; U.S. Pharmacopeial Convention, Rockville, MD, 2000, p. 17-39.

3. The United States Pharmacopeia, 34th ed.; U.S. Pharmacopeial Convention, Rockvill, MD, 2011, p. 3800.

4. Gasco-Lopez, A. I.; Izquierdo-Hornillos, R.; Jiminez, A. J. Chromatogr. A. 1997, 775, 179-185
5. Terrie, Y.C. Managing premenstrual syndrome. http://www.pharmacytimes.com/publications/issue/2011/June2011/Managing-premenstrual -syndrome. Accessed September 2, 2014.

6. Khan, I. U.; Ashfaq, M.; Razzaq, S. N.; Mariam, I. J Liq. Chrom. Rel. Technol. 2013, 36, 1437-1450.

7. Tsvetkova, B.; Pencheva, I.; Zlatkov, A.; Peikov, P. African Journal of Pharmacy and Pharmacology. 2012, 6, 1332-1336.

8. Sindhur Nag, N.; Gouthami, B.; Madhuri, L.; Krishnaveni, N.; Meyyanathan, S. N.; Suresh, B.; Journal of Chemical and Pharmaceutical Research. 2012, 4, 1670-1675.

9. Issa, Y. M.; Hassoun, M. E. M.; Zayed, A. G. J Liq. Chrom. Rel. Technol. 2012, 35, 2148-2161.

10. Karunakaran, K.; Navaneethan, G.; Elango, K. P. Tropical Journal of Pharmaceutical Research. 2012, 11, 99-106.

11. Talluri, M. V. N. K.; Bairwa, M. K.; Dugga, H. H. T.; Srinivas, R. J Liq. Chrom. Rel. Technol. 2012, 35, 129-140.

12. Asci, B.; Donmez, O. A.; Bozdogan, A.; Sungur, S. J Liq. Chrom. Rel. Technol. 2011, 34, 1686-1698.

13. Pirol, O.; Sukuroglu, M.; Ozden, T. E-Journal of Chemistry. 2011, 8, 1275-1279.

14. Shabir, G. A.; Arain, S. A. J Liq. Chrom. Rel. Technol. 2011, 34, 719-729.

15. Luo, Y. Guangxi Yike Daxue Xuebao. 2010, 27, 752-754.

16. Siddiqui, F. A.; Arayne, M. S.; Sultana, N.; Qureshi, F.; J. AOAC Int. 2011, 94, 150-158.

17. Belal, T.; Awad, T.; Clark, C. R. J. Chromat. Sci. 2009, 47, 849854.

18. Wang, H.; Jin, Xiaochin.; Zhao, Liang.; Chen, J.; Lu, L.; Zhang, G.; Pharmaceutical Care and Research. 2010; 10, 198-201.

19. Devon, R.; Lucas, H.; Concordia College Journal of Analytical Chemistry. 2010, 1, 29-33.

20. Stanley, M.; Claude, B. L.; Holder, J. L.; Getek, T. A.; Journal of Chromatography B. 1990, 534, 151-159.

21. Korfmacher, W. A.; Freeman, J. P.; Getek, T. A.; Bloom, J.; Holder, J. L.; Biological Mass Spectrometry. 1990, 19, 191-201.

22. ICH (Q2B); Note for guidance on validation of analytical procedures: methodology. International conference on Harmonization, IFPMA; Geneva 1996. 